\title{
60 лет со ДНЯ ОТКРЫТИЯ МНОГОСЛОЙНОЙ ПАЛЕОЛИТИЧЕСКОЙ СТОЯНКИ им. Ч. ВАЛИХАНОВА
}

\author{
(C) 2019 г. Ж. Таймагамбетов, С. Кунитаке
}

В этом году исполнилось 60 лет со дня открытия Хасаном Алпысбаевичем Алпысбаевым палеолитической стоянки им. Ч. Валиханова. Справедливости ради следует сказать, что вначале исследователь назвал памятник «Палеолитическая стоянка Карасу» по названию близлежащего села, а впоследствии переименовал его в честь ученого-просветителя Ч.Ч. Валиханова. Палеолитическая стоянка им. Ч. Валиханова находится в 143 км к северу от г. Шымкент, на правом берегу третьей надпойменной террасы р. Арыстанды (Байдибекбийский р-н, Туркестанская обл.). Предварительное исследование, проведенное Х.А. Алпысбаевым, позволило установить, что памятник содержит пять культурных слоев, залегающих in situ. Слои располагаются на разных уровнях от современной дневной поверхности и разделяются стерильными прослойками разной мощности.

Ключевые слова: археология, стоянка им. Ч. Валиханова, Х.А. Алпысбаев, культурные слои

\section{Введение}

Стационарные работы на стоянке им. Ч. Валиханова велись Х.А. Алпысбаевым в 1959-1962 гг. [Алпысбаев, 1960], Ж.К. Таймагамбетовым в 1983, 1989-1993 гг., эпизодически в последующие годы, и с 2018 по настоящее время Ж.К. Таймагамбетовым возобновлены раскопки совместно со специалистом из Института культурных ценностей С. Кунитаке (г. Нара, Япония) (рис. 1-4).

В районе расположения стоянки выделены четыре надпойменные террасы р. Арыстанды [Вислогузова, 1961]. Первая терраса - высота ее от уреза воды 1,5-1,8 м, сложена галечниками в основании и суглинками сверху; вторая (2-2,5 м) - гравийногалечными отложениями с редкой примесью валунов; третья (9-12 м) - суглинками; четвертая (20 м) - суглинками, переслаивающимся с галечником.
Описание культурных слоев, выделенных Х. А. Алпысбаевым

Итак, первыци культурный слой вскрыт Х.А. Алпысбаевым на площади $1200 \mathrm{~m}^{2}$ и зафиксирован на глубине 2,30 м от нулевой линии [Алпысбаев, 1979]. Мощность культурного слоя колеблется от 8 до 12 см. Среди 537 каменных изделий выделено 34 нуклеуса, 456 отщепов, 13 пластин и 34 орудия труда. Последние представлены рубящими орудиями (2), скреблами (4), скребками (20), резцами (2), зубчато-выемчатыми орудиями (1), пластинами со следами утилизации (2) и отщепами со следами использования в работе (3). Индустрия указанного слоя относится к начальной стадии верхнего палеолита. Сырьевой материал - халцедон светлых оттенков. Определенное место в индустрии I культурного слоя занимают нуклеусы - разнообразные как 
Таймагамбетов Ж. Кунитаке $\boldsymbol{C}$. 60 лет со дня открытия многослойной палеолитической стоянки им. Ч. Валиханова

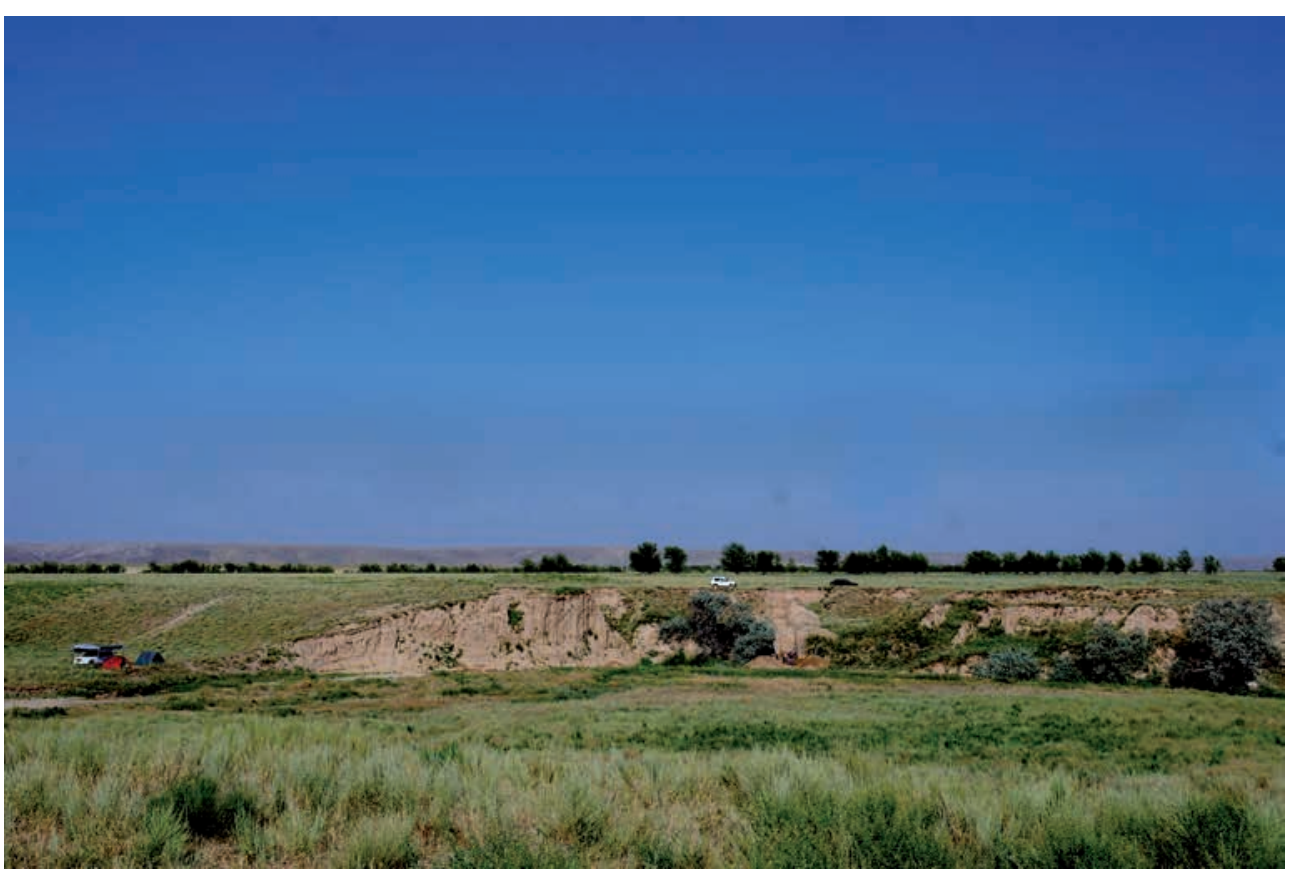

Рис. 1. Стоянка им. Ч. Валиханова. Общчий вид

Fig. 1. Man site of Ch. Valikhanov. General view

по типу, так и по степени их использования (дисковидные двусторонней обработки, одно- и двухплощадочные призматические, неопределенной формы). Пластины с гладкой ударной площадкой, на спинке которых сохранена корка. Концевые скребки на пластинках, отщепах составляют значительную часть орудий. Некоторые из них дополнительно имеют еще ретушь на одной из боковых граней, как на спинке, так и на брюшке. Отличие от нижележащих мустьерских слоев, по словам Х.А. Алпысбаева, состоит в том, что здесь отсутствуют какие-либо очажные слои, угольки, кости животных.

В данном слое, наряду с грубообработанными скреблами, присутствуют и миниатюрные скребочки с полукруглым, тщательно отделанным лезвием. Несмотря на знакомство с новыми приемами обработки камня, сохраняются и старые, о чем свиде- тельствуют дисковидные нуклеусы. Индустрия I культурного слоя стоянки им. Ч. Валиханова относится к начальной стадии верхнего палеолита.

Второй культурный слой вскрыт на площади 406 м $^{2}$ и залегает на глубине от 4,10 до 4,35 м. Мощность слоя от 20 см местами до 25 см. В слое выявлены остатки двух кострищ, охры, очажных пятен, обломков костей животных. Общее число каменного инвентаря состоит из 1233 предметов, среди которых: 51 нуклеус и нуклевидных обломков, отщепы (1114), пластина (1), орудия труда (67). Из числа орудий выделены: рубящие орудия (6), скребла (3), скребки (31), остроконечники (7), резцы (6), выемчатые орудия (1), отбойники (3), рубило (1) и пластины со следами использования в работе (9). Позднемустьерский возвраст рассмотренных орудий не вызывает особых сомнений, который определяется как 


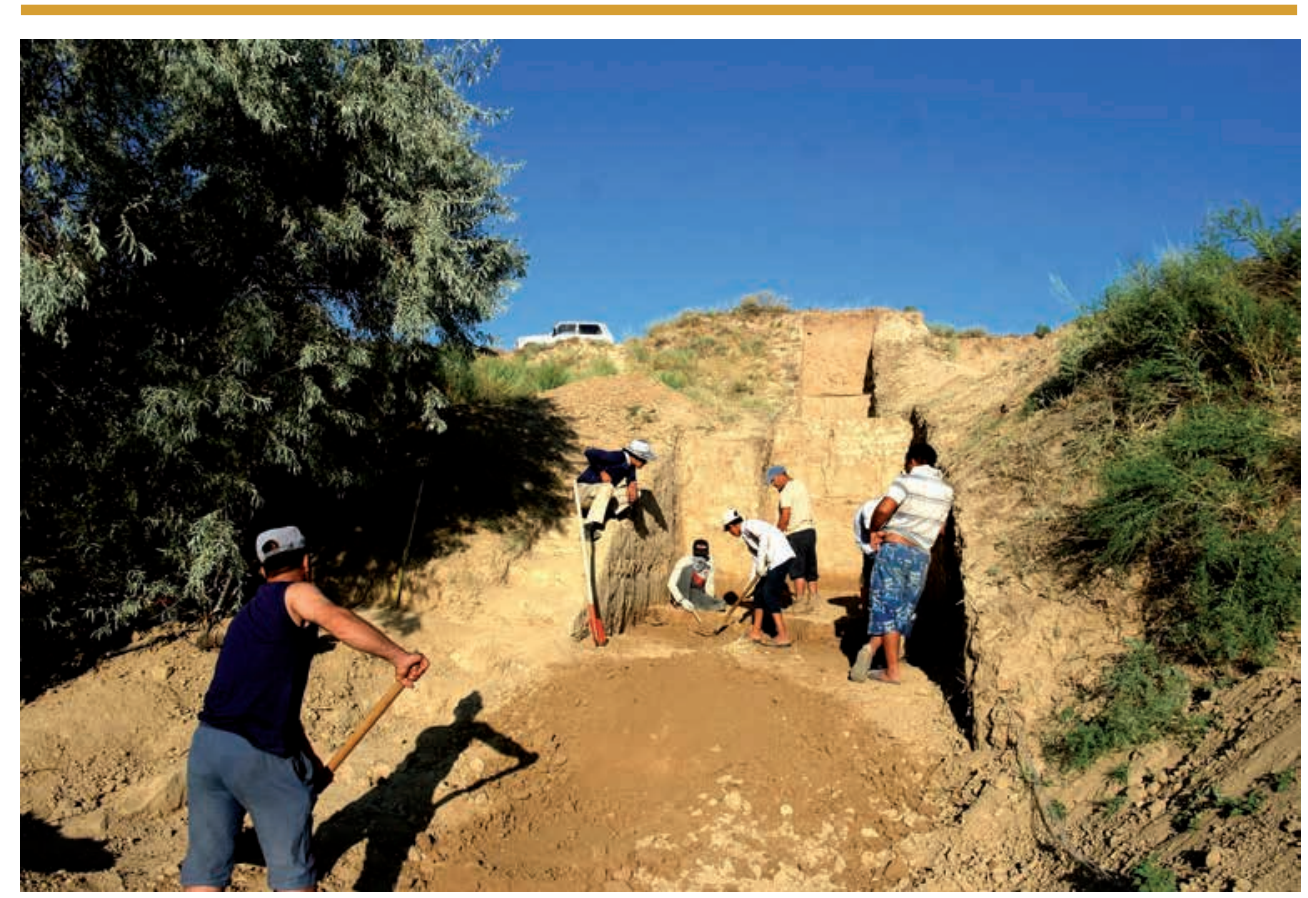

Рис. 2. Стоянка им. Ч. Валиханова. Начало раскопок

Fig. 2. Man site of Ch. Valikhanov. Beginning of excavation

назначением, так и формой, и характером представленных орудий.

Третий культурный слой

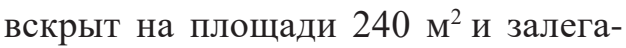
ет на глубине 4,90 м от современной поверхности третьей надпойменной террасы р. Арыстанды. Мощность слоя от 15 см, местами до $20 \mathrm{~cm}$. Здесь обнаружены хорошо сохранившиеся кострища, многочисленные очажные пятна и обломки костей животных. Каменный инвентарь насчитывает всего 443 предмета, в том числе: нуклеусы (28), отщепы (330), пластины (5), сланцы (палеозойские) (5), орудия труда (75). Среди последних: рубящие орудия (10), скребла (6), скребки (39), остроконечники (2), резцы (7), отбойник (1), пластины со следами утилизации (2), отщепы со следами использования (7), галечное изделие (1). Орудия, выявленные в третьем культурном слое, типичные для позднего мустье.
Четвертый культурный слой вскрыт на площади в $140 \mathrm{~m}^{2}$ и залегает на глубине от 5,25 до 5,55 м. Мощность культурного слоя местами доходит до 30 см. Здесь также выявлены каменные изделия, кострища, очажные пятна и остатки охры. Отличительной чертой является наличие обломков костей крупных животных. Среди 946 предметов выделены: нуклеусы (37), отщепы (817), пластины (12), желваки (4), сланцевые изделия (2), орудия труда (74). К последним отнесены: рубящие (13), скребла (8), скребки (10), остроконечники (7), резцы (3), зубчато-выемчатые (1), отбойники (4), пластина со следами использования в работе (1), отщепы со следами утилизации (27). Инвентарь данного слоя также датируется позднемустьерским временем.

Пятый культурный слой вскрыт на площади 198 м $^{2}$ и залегает на глубине 5,50 м от нулевой ли- 
Таймагамбетов Ж. Кунитаке $\boldsymbol{C}$. 60 лет со дня открытия многослойной палеолитической стоянки им. Ч. Валиханова

нии. Мощность его 10 см, местами до 30 см. Культурные остатки представлены обломками костей животных, каменными изделиями, угольками и частицами красной охры. Коллекция каменных изделий насчитывает 2605 предметов. Следует отметить, что для индустрии характерна техника скола грубых отщепов с дисковидных нуклеусов. Из числа каменных изделий выделены: нуклеусы (11), отщепы (2572), желваки (3), орудия труда (19). К последним отнесены: 2 рубящих орудия, 5 скребел, 2 скребка, 9 отщепов со следами утилизации и 1 отбойник. Как видно, орудийный набор не так уж богат по сравнению с индустрией вышележащих культурных слоев. На основе типологического анализа, данных геологии, каменный инвентарь слоя датируется позднемустьерским временем.

O результатах исследований новых культурных слоев

С 1980 г. исследования палеолита в Казахстане ведутся под руководством Ж.К. Таймагамбетова. В 1983 г. были проведены разведочные работы в районе стоянки им. Ч. Валиханова и частичные раскопки на памятнике с целью уточнения стратиграфии [Таймагамбетов, 1984; 1986]. Стационарные работы проводились в 1989-1993 гг. и эпизодически в последующие годы [Таймагамбетов, 1990а-в; 1992a, б; 1995; Taimagambetov, 1998a, b].

Шестой культурный слой выявлен нами в 1993 г. на глубине 7,20 м. Коллекции каменных изделий представляют невыразительные отходы производства. Вероятно, основные находки покоятся в другом месте, а мы затронули периферийную часть.

Однако представления о геологическом и геоморфологическом

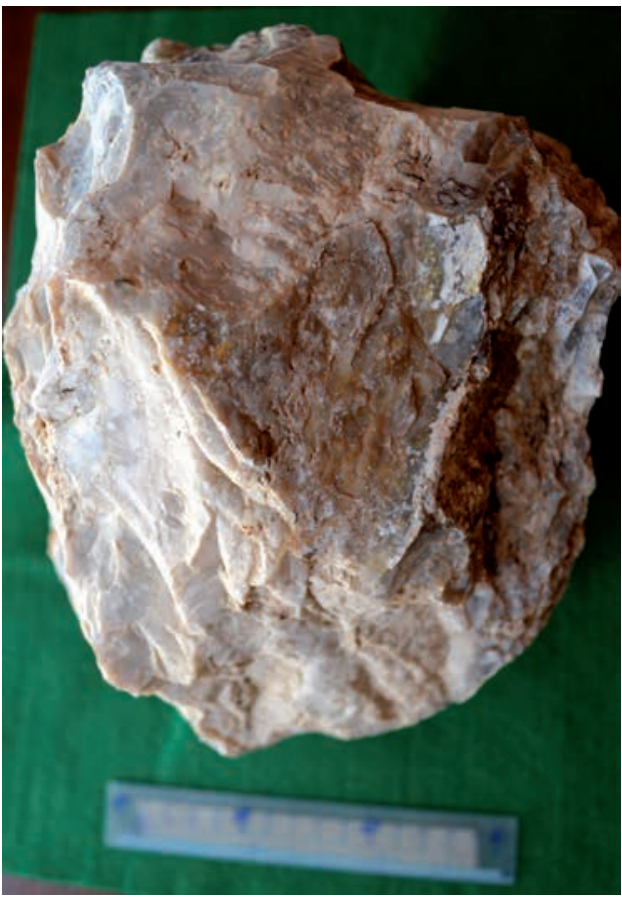

Рис. 3. Стоянка им. Ч. Валиханова, 8-й культурный слой. Нуклеус

Fig. 3. Man site of Ch. Valikhanov, the 8th occupation layer. Nucleus

строении района палеолитической стоянки, выделенные в свое время А.В. Вислогузовой, нами пересматриваются. Три раскопа 1989-1993 гг., заложенные ниже старого раскопа Х.А. Алпысбаева, а также выше по течению, показали, что в строении разреза участвуют три пачки:

- верхняя - до глубины 3 м - имеет двучленное строение и по своему генезису относится к склоновым, делювиальным накоплениями. Верхняя половина делювиа - рыхлая, макропористая, с многочисленными следами от корней растений и кротовинами. Нижняя половина имеет меньше следов от корней растений, она боле плотная;

- средняя пачка - это хорошо диагностируемыелессово-почвенные слои, отражающие этап эолового 
(преимущественно) и почвенного осадконакопления. Эта часть разреза накапливалась в стабильных, достаточно засушливых (аридных) условиях. Нижняя часть разреза на глубине 5-10 м относится в раскопе 3 к склоновым делювиальным накоплениям и хорошо подчеркивает палеорельф того времени. На этом участке выше по течению р. Арыстанды, вероятно, существовал мыс, на склонах которого в сторону долины происходило накопление делювия;

- нижняя (третья) пачка относится к аллювию Праарыстанды. В сложении этой пачки участвуют слои разнозернистого гравийного песка с прослоями галечника. Отложения в общем напоминают современный аллювий р. Арыстанды.

Таким образом, разрезы раскопов следует интерпретировать иначе, чем это представлялось ранее. Понятиям об аллювиальном генезисе отложений, вмещающих культурные слои стоянки, противоречит также неодинаковое строение второй террасы. Так, на правом берегу она (или уровни, соответствующие второй террасе) сложены лессами; по левобережью - в разрезах террасы наблюдается нормальный песчано-гравийный и галечниковый аллювий.

Последовательность геологических событий по вновь полученным данным можно предполагать следующим образом.

Крупная депрессия тектонического происхождения, расположенная между горами Большого и Малого Каратау, залегает гипсометрически много ниже средней высоты положительных форм гор Каратау и служит естественной ловушкой (ветровая тень) для пыли, выносимой как с юга - со стороны Восточных Кызылку- мов, так и с севера - песчаных массивов Моинкум. Даже в настоящее время пыльные бури, проносясь над хребтами гор Каратау, оставляют в зоне затишья большую часть своих осадков, которые перекрывают днища депрессий и склоны прилегающих гор. Река Арыстанды пересекает эту депрессию в меридиональном направлении с севера на юг, проложив свое русло в периферийной зоне лессового плато и коренного склона, меловыми и палеогеновыми породами.

Именно сочетание в разрезе правобережья р. Арыстанды аллювиальных, делювиальных, лессовых пачек позволяет нам считать, что p. Арыстанды действовала периодически и временами почти полностью исчезала во время аридных этапов, когда долина заполнялась делювиальными и эоловыми (лессовыми) отложениями. Этот район находится в пустынной зоне, но его положение, как «метеорная» впадина, и относительная приподнятость над присырдарьинскими и предчуйскими песчаными пустынями определяли несколько отличающиеся микроклиматических условия, в которых существовали полупустыни на открытых пространствах и участки с тугаями и небольшими лесами на склонах гор Каратау, о чем свидетельствуют данные Л.Н. Чупиной.

Формирование эоловых отложений и почв средней пачки совпадает с глубокой аридной фазой конца среднего и началом верхнего плейстоцена. Саму стоянку следует считать не аллювиальной, а лессовой.

Стратификация толщи на основе педогенных признаков, выполненная в 1993 г. профессором М.И. Дергачевой, подтвердила в целом предложенное стратиграфическое описание 
Таймагамбетов Ж. Кунитаке $\boldsymbol{C}$. 60 лет со дня открытия многослойной палеолитической стоянки им. Ч. Валиханова

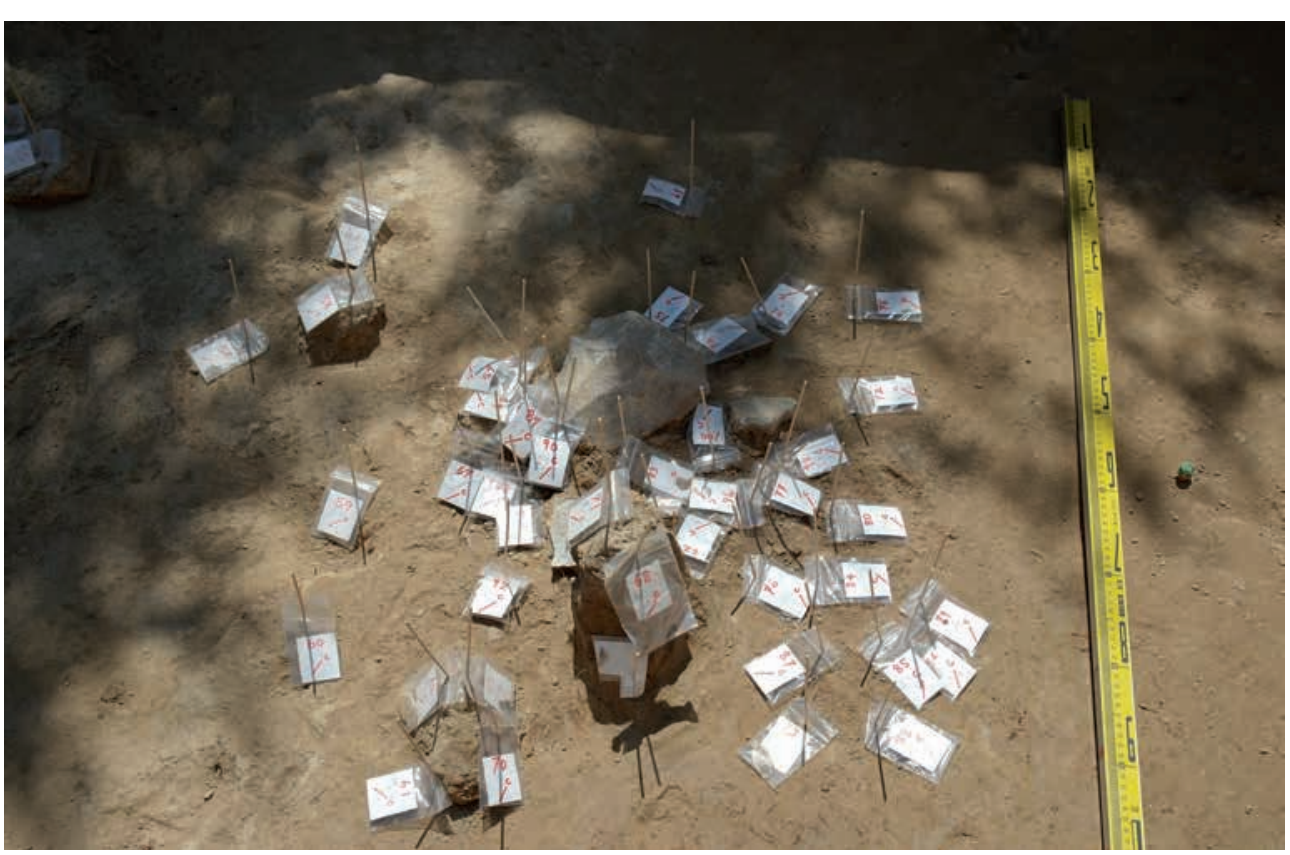

Рис. 4. Стоянка им. Ч. Валиханова, 9-й культурный слой. Рабочая площадка Fig. 4. Man site of Ch. Valikhanov, the 9th occupation layer. Work site

разреза, однако позволила уточнить ее расчленение и выделить в верхней части разреза толщу современной почвы (до глубины 1,5-2,0), лессовую толщу (до 3,8 м), формировавшуюся в более аридных условиях, чем предыдущая (с глубины 3,9 до 6 м и ниже).

В 2018-2019 гг. КазахстанскоЯпонская археологическая экспедиция Национального музея РК и Научно-исследовательского института культурных ценностей Нара во главе с профессором Садакатцу Кунитаке проводила работы по уточнению стратиграфического разреза на стоянке им. Ч. Валиханова в Южном Казахстане. Впервые, из-за отсутствия воды в р. Арыстанды, удалось заложить разведочную траншею сверху вниз до основания реки 2 м шириной и 25 м длиной. Всего пло-

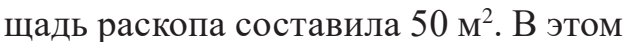
году раскопки были расширены и доведены до глубины 10 м.
Если ранее было известно о шести культурных слоях, залегающих in situ, то в результате работ последних двух лет впервые на стоянке в нижних отложениях выявлены еще три культурных слоя и общее число их достигло девяти, что свидетельствует об обитании первочеловека на протяжении длительного времени в одном и том же месте. Слои располагаются на разных уровнях от современной дневной поверхности и разделяются стерильными прослойками разной мощности.

Седьмой культурный слой залегает на глубине 6,90 м от нулевой линии. Мощность его 20 см. Этот культурный слой чуть выше, чем шестой культурный слой, обнаруженный Ж.К. Таймагамбетовым (7,20 м). Каменные изделия в основном - маленькие отщепы.

Восьмой культурный слой обнаружен впервые и залегает на глубине 8,40 м от нулевой линии. Мощ- 
ность его 30 см. Здесь выявлено много каменных изделий. Особенно выделяется очень большое ядро сферы - заготовка (нуклеус) из светлого халцедона с многочисленными снятиями отщепов.

Девятый культурный слой обнаружен впервые и залегает на глубине 9,20 м от нулевой линии. Мощность его 20 см. Культурный слой важен для хронологии отложений. В девятом культурном слое обнаружены пластины и торцовый нуклеус для снятия пластин. Отметим выявление в этом году в культурном слое рабочей площадки - фиксации крупного нуклеуса и более 150 отщепов и пластин вокруг него. В будущем будет произведен ремонтаж нуклеуса.

Следует заметить, что фиксированные нами от репера 5-7 культурные слои были найдены между пятью ранее обнаруженным культурными слоями Х.А. Алпысбаева $(5,50$ м) и шестым культурным слоем, выявленным Ж.К. Таймагамбетовым (7,20 м). Восьмой и девятый культурные слои залегали ниже, чем шестой культурный слой, обнаруженный в свое время Ж.К. Таймагамбетовым (7,20 м). Здесь следует отметить, что 8 и 9 культурные слои залегали в лессе, мощность не превышала 10-15 см. Так, девятый культурный слой выявлен сейчас, когда в р. Арыстанды ушла вода. Предварительно можно сказать, что это самый низко залегающий культурный слой, он может относиться к начальному периоду верхнего палеолита.

Для проведения анализов от 5 до 9 культурного слоя были отобраны образцы почв. Это сделано с целью определения точной датировки памятника, что делается впервые для нижележащих слоев.

\section{Фауна и флора стоянки}

Не останавливаясь на классификации каменной индустрии, подробно описанной Х.А. Алпысбаевым и одним из авторов данной статьи, коротко скажем о фаунистических материалах стоянки.

Основная часть остеологического материала, за исключением нескольких отдельных фрагментов, состоит из мелких обломков костей животных, чаще всего трубчатых. В слоях обнаружены челюсти лошади, бизона, рога сайги и благородного оленя. Наличие костных остатков лошади и сайги свидетельствует о степном характере ландшафта. В пользу этого говорят и данные спорово-пыльцевого анализа, взятые из разреза палеолитической стоянки им. Ч. Валиханова. Состав споровопыльцевого анализа свидетельствует о сухом климате, что и способствовало накоплению лессовидных суглинков на стоянке.

\section{Заключение}

Стратифицированный материал многослойной палеолитической стоянки им. Ч. Валиханова, содержащий девять культурных слоев (!) и отражающий культурно-исторические этапы верхнего палеолита, дает возможность считать стоянку им. Ч. Валиханова опорным памятником при решении вопросов хронологии и периодизации палеолитических памятников Казахстана. Это одна из уникальных, многослойных палеолитических стоянок, связанная с антропогеновыми отложениями.

Работы на стоянке им. Ч. Валиханова будут еще продолжены и рассчитаны они на долгие годы. 
Таймагамбетов Ж. Кунитаке $\boldsymbol{C}$. 60 лет со дня открытия многослойной палеолитической стоянки им. Ч. Валиханова

\section{ЛИТЕРАТУРА}

1. Алпысбаев X.А. Первая многослойная палеолитическая стоянка в Казахстане // ВАН КазССР. 1960. № 11. С. 103-106.

2. Алпысбаев Х.А. Памятники нижнего палеолита Южного Казахстана. АлмаАта: Наука, 1979. 208 с.

3. Вислогузова А.В. Бассейн реки Арыстанды // Путеводитель по геологическим маршрутам Южного Казахстана. Алма-Ата: изд-во АН КазССР, 1961. С. 10-23.

4. Таймагамбетов Ж.К. Периодизация эпохи палеолита Южного Казахстана (по материалам стоянки имени Ч. Валиханова): автореф. дис. ... канд. ист. наук. Новосибирск, 1984. 25 с.

5. Таймагамбетов Ж.К. Исследования каменной индустрии на стоянке им. Ч. Валиханова // Археологические и этнографические исследования Восточной Сибири: тез. докл. к региональной конф. (г. Иркутск, 13-15 октября 1986 г.). Иркутск: изд-во ИГУ, 1986. С. 72-73.

6. Таймагамбетов Ж.К. К проблеме эволюции каменной индустрии на стоянке им. Ч. Валиханова // Тез. докл. научн.-практ. конф., посвящ. 70-летию организации Чимкентского областного историко-краеведческого музея (10-12 октября 1990 г.). Алма-Ата, 1990аa. С. 50-52.

7. Таймагамбетов Ж.К. О значении многослойной палеолитической стоянки им. Ч. Валиханова // Хроностратиграфия палеолита Северной, Центральной и Восточной Азии и Америки: тез. докл. Междунар. симпозиума. Новосибирск, 1990б. C. $281-283$.

8. Таймагамбетов Ж.К. Палеолитическая стоянка им. Ч.Ч. Валиханова. АлмаАта: Наука, 1990в. 128 с.

9. Таймагамбетов Ж.К. Геоморфологическая ситуация и стратиграфия многослойной палеолитической стоянки им. Ч.Ч. Валиханова // Палеоэкология и расселение древнего человека в Северной Азии и Америке: тез. Междунар. симпозиума. Красноярск, 1992а. С. 234-237.

10. Таймагамбетов Ж.К. К характеристике каменных изделий из стоянки им. Ч.Ч. Валиханова // Валихановские чтения: тез. докл. республ. конф. (25-28 марта 1992 г.). Кокшетау, 1992б. С. 45-47.

11. Таймагамбетов Ж.К. Новые данные о стоянке им. Ч.Ч. Валиханова // АтаМура: сб. статей, посвящ. 75-летию Южно-Казахстанского музея. Шымкент, 1995. C. $43-45$.

12. Taimagavbetov Zh.K. De L' importance de la sequence paleolithique du site Ch.Ch. Valikhanov // Recherches archelogiques Au Kazakhstan. T. X, de Boccard. Paris, 1998a. P. 141-143.

13. Taimagavbetov Zh.K. De l'importance de la station paleolithique a pluseiurs niveaux "Tch. Valikhanov" // Prehistoire d'Anatolie Genese des deux mondes - Actes du collogue international (Liege, 28 avril - 3 mai 1997). Liege, 1998b. P. 845-848.

\section{Сведения об авторах:}

Таймагамбетов Жакен - доктор исторических наук, профессор, членкорреспондент НАН РК, главный научный сотрудник, Национальный музей РК (г. Нур-Султан, Казахстан); zhaken.taimagambetov@gmail.com

Кунитаке Садакатцу - доктор $\mathrm{PhD}$, старший научный сотрудник, Национальный Институт культурных ценностей Нара (г. Нара, Япония); kunitakesadakatsu@gmail.com 


\title{
Ш. УӘЛИХАНОВ АТЫНДАҒЫ КӨПҚАТПАРЛЫ ПАЛЕОЛИТ ҚОНЫСЫНЫН АШЫЛҒАНЫНА 60 ЖЫЛ
}

\author{
Ж. Таймағамбетов, С. Кунитаке
}

Үстіміздегі жылы Хасан Алпысбайұлы Алпысбаев ашқан Ш. Уәлиханов атындағы палеолит қонысының ашылғанына 60 жыл толды. Шындығын айтқанда, зерттеуші алғашында ескерткішті жақын маңдағы елдімекеннің атауына сай «Қарасу палеолит қонысы» деп атайды да, кейіннен ғалым-ағартушы Ш. Уәлихановтың құрметіне атауын қайта өзгертеді. Ш. Уәлиханов атындағы палеолит қонысы Шымкент қаласынан солтүстікке қарай 143 шақырым қашықтықта, Арыстанды өз. үшінші жайылмаүсті террасаларының оң жағалауында орналасқан (Бәйдібек би ауданы, Түркістан обл.). Х.А. Алпысбаевтың алдын-ала жүргізген зерттеулері ескерткіштің in situ-ге жататын бес мәдени қабаттан тұратындығын анықтауға мүмкіндік берді. Қатпарлар қазіргі күндізгі үстіңгі қабаттан түрлі деңгейде орналасқан және әртүрлі зарарсыздандырылған қабаттардың қатпарларымен бөлінеді.

Түйін сөздер: археология, Ш. Уәлиханов атындағы қоныс, Х.А. Алпысбаев, мәдени қабат

\section{0 years from the date of OPENING of the MULTILAYERED PALEOLITHIC MAN SITE of Ch. VALIKHANOV}

\section{Zh. Taimagambetov, S. Kunitake}

This year marked the 60th anniversary of opening of Paleolithic man site named after Ch. Valikhanov by Khasan A. Alpysbayev. To be fair it is necessary to tell that in the beginning the researcher called the site "Paleolithic man site of Karasu" by the name of nearby village, and subsequently, renamed it into honor of the scientist-educator Ch.Ch. Valikhanov. Paleolithic man site named after Ch. Valikhanov is $143 \mathrm{~km}$ north of Shymkent on the right bank of the third overhead terrace of the Arystandy River (Baidibek area, Turkistan Region). Preliminary research conducted by Kh.A. Alpysbayev revealed that the monument contains five cultural layers lying in situ. The layers are located at different levels from the modern daylight surface and are separated by sterile layers of different power. layers

Keywords: archaeology, Ch. Valikhanov man site, Kh.A. Alpysbayev, cultural

\section{REFERENCES}

1. Alpysbayev, Kh. A. 1960. In Vestnik Akademii nauk KazSSR (Bulletin of the Academy of Sciences of the Kazakh SSR), 11, 103-106 (in Russian).

2. Alpysbayev, Kh. A. 1979. Pamyatniki nizhnego paleolita Yuzhnogo Kazahstana (The sites of the Lower Paleolithic of Southern Kazakhstan). Alma-Ata: "Nauka" Publ. (in Russian).

3. Visloguzova, A. V. 1961. In Putevoditel po geologicheskim marshrutam Yuzhnogo Kazahstana (Guide to Geological Routes of Southern Kazakhstan). Alma-Ata: Academy of Sciences of the Kazakh SSR Publ., 10-23 (in Russian).

4. Taimagambetov, Zh. K. 1984. Periodizaciya epohi paleolita Yuzhnogo Kazahstana (po materialam stoyanki imeni Ch. Valihanova): avtoref. dis. ... kand. ist. nauk (Periodization of the Paleolithic era of Southern Kazakhstan (based on materials from the Ch. Valikhanov site): abstract. dis. ... cand. hist. sciences. Novosibirsk (in Russian).

5. Taimagambetov, Zh. K. 1986. In Arheologicheskie i etnograficheskie issledovaniya Vostochnoj Sibiri (Archaeological and ethnographic studies of Eastern Siberia). Irkutsk: Irkutsk State University Publ., 72-73 (in Russian). 
Таймагамбетов Ж. Кунитаке $\boldsymbol{C}$. 60 лет со дня открытия многослойной палеолитической стоянки им. Ч. Валиханова

6. Taimagambetov, Zh. K. 1990a. In Tez. dokl. nauchn.-prakt. konf., posvyashch. 70-letiyu organizacii Chimkentskogo oblastnogo istoriko-kraevedcheskogo muzeya (Thesis. doc. scientific-practical Conf. The 70th anniversary of the organization of the Chimkent Regional Museum of History and Local Lore). Alma-Ata, 50-52 (in Russian).

7. Taimagambetov, Zh. K. 1990b. In Hronostratigrafiya paleolita Severnoi, Centralnoi i Vostochnoi Azii i Ameriki (Chronostratigraphy of the Paleolithic of North, Central and East Asia and America). Novosibirsk, 281-283 (in Russian).

8. Taimagambetov, Zh. K. 1990v. Paleoliticheskaya stoyanka im. Ch.Ch. Valikhanova (Ch.Ch. Valikhanov paleolithic site). Alma-Ata: "Nauka" Publ. (in Russian).

9. Taimagambetov, Zh. K. 1992a. In Paleoekologiya i rasselenie drevnego chelove$k a v$ Severnoi Azii i Amerike (Paleoecology and the resettlement of an ancient person in North Asia and America). Krasnoyarsk, 234-237 (in Russian).

10. Taimagambetov, Zh. K. 1992b. In Valikhanovskie chteniya (Valikhanov readings). Kokshetau, 45-47 (in Russian).

11. Taimagambetov, Zh. K. 1995. In Ata-Mura. Shymkent, 43-45 (in Russian).

12. Taimagavbetov, Zh. K. 1998a. In Recherches archelogiques Au Kazakhstan. T. X, de Boccard. Paris, 141-143.

13. Taimagavbetov, Zh. K. 1998b. In Prehistoire d'Anatolie Genese des deux mondes - Actes du collogue international. Liege, 845-848.

\section{About the Authors:}

Taimagambetov Zhaken. Doctor of Historical Sciences, Professor, Corresponding Member of the National Academy of Sciences of the Republic of Kazakhstan, Chief Researcher, National Museum of the Republic of Kazakhstan, Nur-Sultan, Kazakhstan; zhaken.taimagambetov@gmail.com

Kunitake Sadakatsu. PhD, Senior Researcher, Nara National Research Institute for Cultural Properties, Japan; kunitakesadakatsu@gmail.com

Мүдделер қақтығысы туралы ақпаратты ашу. Авторлар мүдделер қақтығысының жоқтығын мәлімдейді. / Раскрытие информации о конфликте интересов. Авторы заявляют об отсутствии конфликта интересов.

/ Disclosure of conflict of interest information. The authors claims no conflict of interest.

Мақала туралы ақпарат / Информация о статье / Information about the article.

Редакцияға түсті / Поступила в редакцию / Entered the editorial office: 09.09.2019.

Рецензенттер мақұлдаған / Одобрено рецензентами / Approved by reviewers: 16.09.2019.

Жариялауға қабылданды / Принята к публикации / Accepted for publication: 23.09.2019. 